\title{
Dimitrios Phitos
}

\section{Reinstating Campanula nisyria as a distinct species of Sect. Quinqueloculares (Campanulaceae)}

\begin{abstract}
Phitos, D.: Reinstating Campanula nisyria as a distinct species of Sect. Quinqueloculares (Campanulaceae). - F1. Medit. 31: 101-107. 2021. — ISSN: 1120-4052 printed, 2240-4538 online.

The recently emerging trend to define Campanula nisyria as a synonym of $C$. hagielia provided the incentive for the publication of the current paper. The morphological differences of the two species, along with their different geographical distribution are supplemented by recent molecular data, which reinforce the clear distinction of the two aforementioned species.
\end{abstract}

Key words: Campanula hagielia, morphology, taxonomy, distribution.

\section{Introduction}

The decision to prepare this article stemmed from the examination of the available Campanula material, for the PhD Thesis of our collaborator Eleni Liveri (2021).

Thus, after several decades, I return to the study of the Campanula lyrata Lam. group, which on the Aegean islands and W Anatolia presents a unique polymorphism, the center of which is on Rhodes island and the surrounding islets. I believe that K. H. Rechinger was the first to clearly express the mentioned polymorphism in his fundamental work "Flora Aegaea - Flora der Inseln und Halbinseln des ägäischen Meeres" (1943), noting (p. 595): "Der Formenkreis der Sect. Medium Subsect. Quinqueloculares bedürfte dringend einer monographischen Bearbeitung, doch muss diese auf späteren Zeitpunkt verschoben werden". Already, in the first publication on the group of the quinquelocular Campanula species (Phitos 1965), we emphatically pointed out its polymorphism. Also Carlström (1987), who studied the flora of Rhodes island and the surrounding islets, mentions, in relation to this: "The quinquelocular Campanula species on the East Aegean islands and in W Anatolia are problematic and experimental work on the group is badly needed". In addition, Eddie \& Ingrouille (1999) devote another paper to the "Polymorphism in the Aegean "five-loculed" species of the genus Campanula section Quinqueloculares".

In the process of examining the above-mentioned, collected Campanula material, we also turned to the recent, two-volume work by Arne Strid "Atlas of the Aegean 
Flora" (2016). In that work, Campanula nisyria Papatsou \& Phitos is mentioned as synonym of $C$. hagielia Boiss.

\section{Taxonomy}

Campanula nisyria Papatsou \& Phitos in Notes Roy. Bot. Gard. Edinburgh 34: 203 (1975). Holotype: - [GREECE, EAST AEGEAN ISLANDS]. No 446. Ins. Nisyros (Dodekanisa): in ditione pagi Emporios, in petrosis vulc., ca. 150 m, 29.5.1971, S. Papatsou (Herb. Phitos \& Kamari in UPA!). - Fig. 1.

Campanula nisyria is a stenoendemic species that grows only on Nisyros island (East Aegean Islands).

It should be pointed out from the beginning that $C$. nisyria grows mostly on volcanic substrates. No other species of the C. lyrata group has been found on Nisyros island. Besides, on Rhodes island, despite the unrestrained polymorphism of the $C$. lyrata group, no individuals have been found so far, bearing the characteristic features of C. nisyria.

Table 1 presents the morphological differences between Campanula nisyria and $C$. hagielia, based also on the herbar-material, collected in the meanwhile. However, we consider useful to further comment on some characteristic features of $C$. nisyria.

As shown in Fig. 1, the most characteristic traits of Campanula nisyria are its robust and usually sole stem, up to $70 \mathrm{~cm}$ tall and the leaves in rosettes, oblong-ovate to

Table 1. The main morphological differences between Campanula nisyria and C. hagielia.

\begin{tabular}{|l|l|}
\hline Campanula nisyria & Campanula hagielia \\
\hline $\begin{array}{l}\text { Plants long hirsute, scabrid, sometimes } \\
\text { strigose }\end{array}$ & Plants softly hirsute or pubescent \\
\hline $\begin{array}{l}\text { Stem usually single, erect, up to } 70 \mathrm{~cm}, \\
\text { rarely with 1-2 lateral branches }\end{array}$ & $\begin{array}{l}\text { Stems usually many (1-)2-3(-4), suberect, } \\
\text { up to } 60 \mathrm{~cm} \text {, irregularly branched or stems } \\
\text { flexuose }\end{array}$ \\
\hline $\begin{array}{l}\text { Basal leaves (8-)12-18(-21) cm long, } \\
\text { oblong-lanceolate to oblong-ovate, } \\
\text { crenate, rarely bicrenate }\end{array}$ & $\begin{array}{l}\text { Basal leaves }(6-) 10-16(-20) \mathrm{cm} \text { long, } \\
\text { cordate or ovate-cordate, serrate, } \\
\text { lobulated-petiolate or sublyrate, crenate to } \\
\text { bicrenate }\end{array}$ \\
\hline $\begin{array}{l}\text { Flowers usually 2-3 together, or sessile to } \\
\text { subsessile, forming a spikelet-like } \\
\text { inflorescence }\end{array}$ & $\begin{array}{l}\text { Flowers usually solitary, pedicelate or } \\
\text { subpedicelate }\end{array}$ \\
\hline $\begin{array}{l}\text { Corolla tube infundibular; calyx lobe } \\
\text { ovate, clearly less than } 1 / 2 \text { of corolla tube } \\
\text { length; appendages densely incanus- } \\
\text { hirsute or albo-strigose }\end{array}$ & $\begin{array}{l}\text { Corolla broadly cylindrical to infundibular; } \\
\text { calyx lobe variable in form and length; } \\
\text { appendages hirsutulous to hirsute }\end{array}$ \\
\hline
\end{tabular}




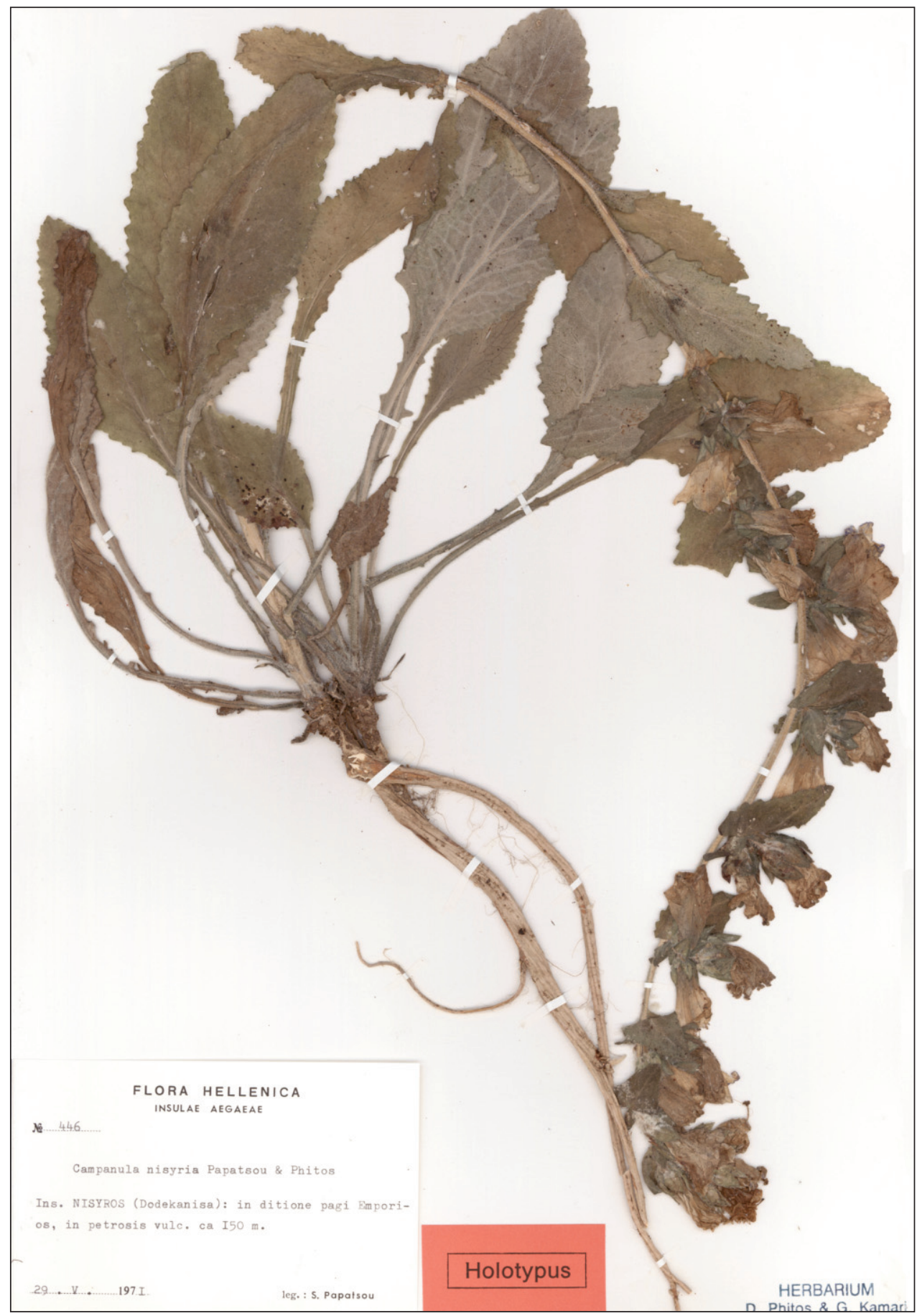

Fig. 1. Holotype of Campanula nisyria (Herb. Phitos \& Kamari in UPA). 
oblanceolate, reaching $22 \mathrm{~cm}$ in length. The main stem usually bears 1-2 lateral stems. The rarely appearing forms with short stems that grow from the base of the plant, are derived from individuals, in which the main stem is missing, most likely eaten by sheep and goats; herding is one of the common practices for Nisyros residents, taking place all over the island. In this case, the common habitus of $C$. nisyria changes, however, the extensive damage on the main stem is visible.

Campanula hagielia Boiss., Fl. Orient. 3: 899 (1875).

Lectotype (designated here): - [GREECE, EAST AEGEAN ISLANDS], Rhodes: Rochers du mont Santo Elio près Salakos, 30 Mai 1870, Bourgeau 217, sub Campanula lyrata Lam. (G00748548 photo! - SIB 427802/1, image available at http://www.ville-ge.ch/musinfo/bd/cjb/chg/adetail.php?id=550546\&base=img). Fig. 2.

In the Lectotype of Campanula hagielia (Fig. 2) it is clear that, apart from a single main stem, at least two secondary shoots grow from its base with stemmed single flowers. Moreover in Fig. 3, the leaf form in the two rosettes, that have been collected from the locus classicus, must be considered to be the typical form for this species. It is also clear in this case, that the different variants in leaf form are common, due to the polymorphism (Table 1).

In addition to the above morphological differences, recent molecular data (Liveri \& al. 2020) reveal that Campanula nisyria belongs to a well-supported clade, together with five Turkish endemics, whereas C. lyrata and C. hagielia form a different clade; both clades, though, are included in a larger one, consisting of taxa distributed in SE Aegean and Anatolia.

With the above remarks and with the hope that it has become at least clear that Campanula nisyria constitutes a distinguished species, this does not mean that the unusual polymorphism of $C$. lyrata, mainly on Rhodos island and the surrounding islets has been solved. In fact, further work is required, which is left to the younger colleagues, particularly in view of the writing of "Flora Hellenica".

Besides, the author himself has repeatedly commented that the Aegean region with the multitude of islands and islets, is considered a natural laboratory for the evolution of living organisms, a result of which is also the formation of the above-mentioned polymorphism. Without doubt, this creates several difficulties in the taxonomy of the plants and especially in the polyphyletic genus Campanula, commonly leading to mistakes that even the author has not avoided in the past.

\section{Acknowledgements}

To our collaborator, Dr. E. Liveri, who performed her study on Campanula section Quinqueloculares with molecular methods, I express my thanks for her help. I also thank our collaborator, Dr. G. Mitsainas, who, like always, checked the English language of the manuscript. 


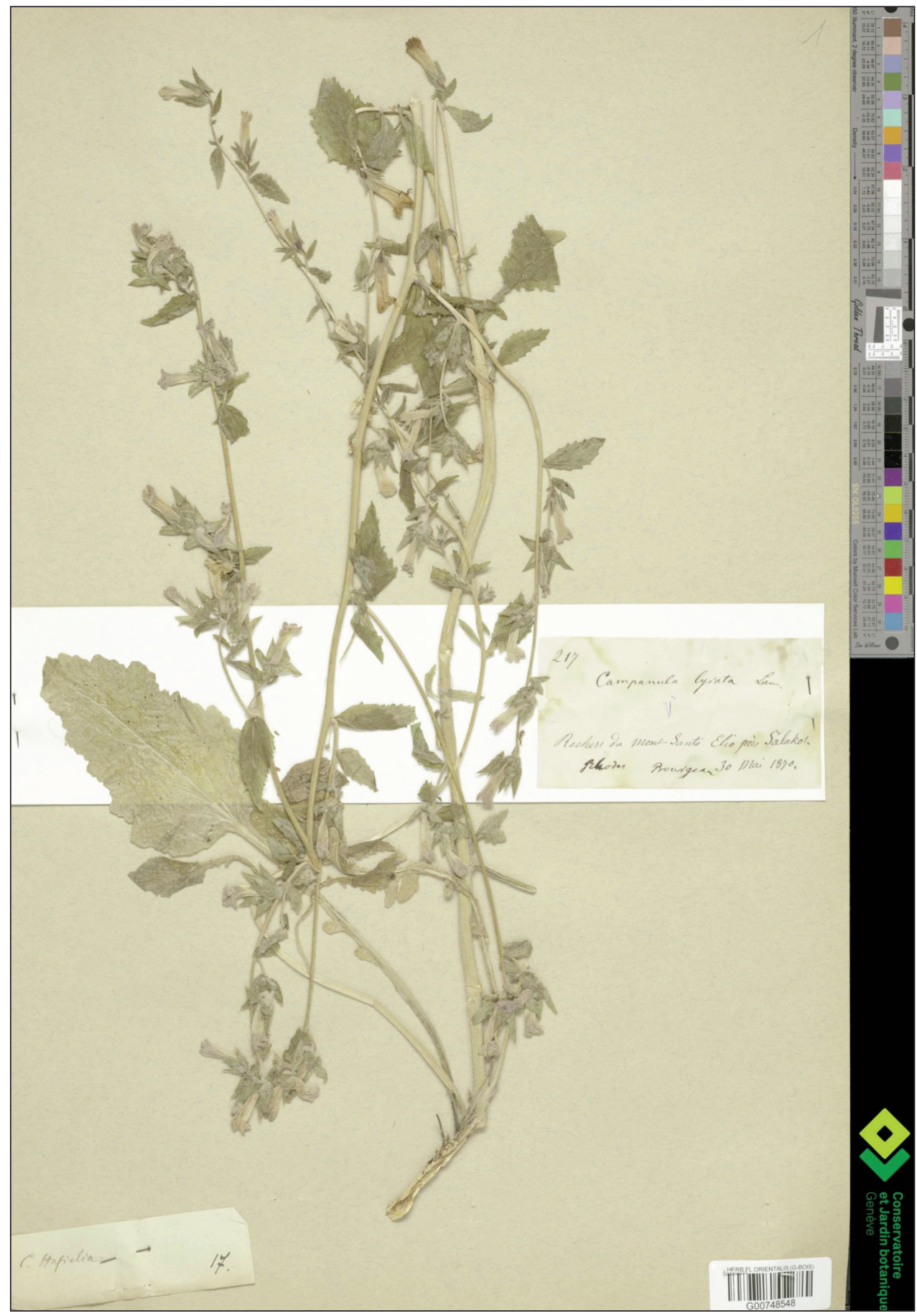

Fig. 2. Lectotype (designated here) of Campanula hagielia (Herb. Genève). 


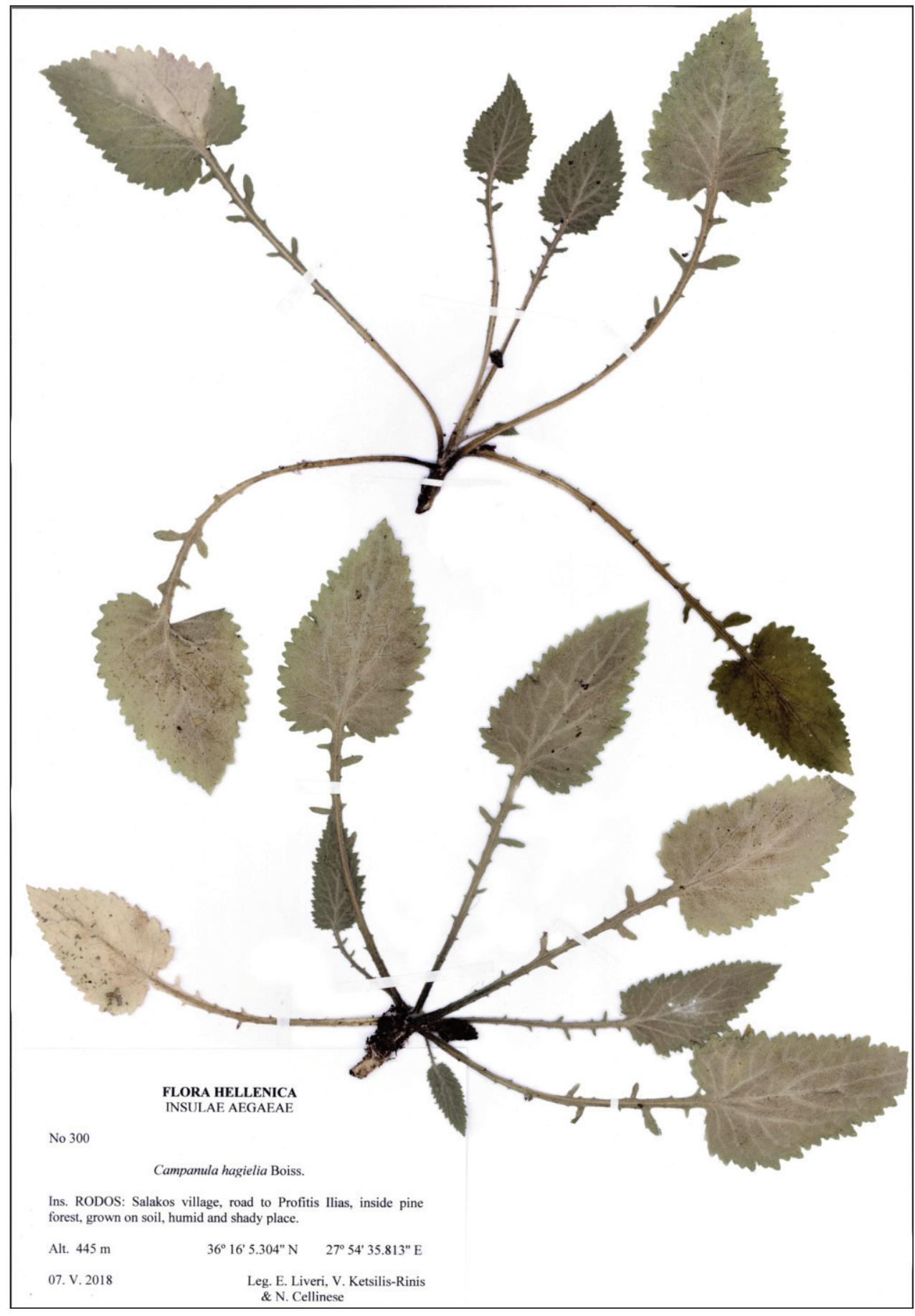

Fig. 3. Rosettes leaves of Campanula hagielia from Rhodos island (locus classicus). 


\section{References}

Carlström, A. 1987: A survey of the flora and phytogeography of Rodhos, Simi, Tilos and the Marmaris Peninsula (SE Greece, SW Turkey). - PhD Thesis, Department of Systematic Botany, University of Lund, Sweden.

Davis, P. H. (ed.) 1978: Flora of Turkey and the East Aegean Islands, 6. - Edinburgh.

Eddie, W. M. M. \& Ingrouille, W. J. 1999: Polymorphism in the Aegean "five-loculed" species of the genus Campanula, section Quinqueloculares (Campanulaceae). - Nordic J. Bot. 19: 153169. https://doi.org/10.1111/j.1756-1051.1999.tb00659.x

Liveri, E. 2021: Phylogeny and biogeography of Campanula L. section Quinqueloculares (Boiss.) Phitos (Campanuloideae, Campanulaceae). - PhD Thesis, Department of Biology, School of Natural Sciences, University of Patras, Greece [in English with an extensive Greek summary].

—, Crowl, A. A., Mavrodiev, E., Yıldırım, H., Kamari, G. \& Cellinese, N. 2020: Another piece of the puzzle, another brick in the wall: The inevitable fate of Campanula section Quinqueloculares (Campanulaceae: Campanuloideae). - Taxon 69(6): 1239-1258. https://doi.org/10.1002/tax.12372

Papatsou, S. \& Phitos, D. 1975: Two new taxa from eastern Aegean. - Notes Roy. Bot. Gard. Edinburgh 34: 203-204.

Phitos, D. 1965: Eine neue art der Gattung Campanula aus der Ägäis. - Mitt. Bot. Staatssamml. München 5: 121-124.

Strid, A. 2016: Atlas of the Aegean Flora, 1. Text \& Plates. - Englera 33(1): 1-700.

Address of the author:

Dimitrios Phitos,

Botanical Institute, Division of Plant Biology, Department of Biology, University of Patras, GR-26504, Greece. E-mail: dphitos@upatras.gr 
